\title{
COVID-19 MEMUDARKAN RASA KEMANUSIAAN TERHADAP SESAMA DAN IMPLIKASINYA BAGI ORANG PERCAYA
}

\author{
Simon \\ Sekolah Tinggi Teologi Salatiga \\ Email: simonpetrus45144@gmail.com \\ Lindin Anderson \\ Sekolah Tinggi Teologi Nusantara \\ Email: lindinanderson87@gmail.com
}

\begin{abstract}
Article History
Submit:

26 October 2020

Revised:

9 Desember 2020

Published:

18 Desember

2020
\end{abstract}

\begin{abstract}
:
This paper highlights the fading sense of humanity towards others due to the influence of Covid-19.The understanding of humanity as referred to in this paper, of course, departs from a Christian theological perspective. The meaning of humanity means empathy or concern in understanding the difficulties experienced by others, as well as being an active actor in overcoming the burdens of other people's lives without seeking profit. The method used in this paper is descriptive qualitative with a phenomenological approach. The results of this discussion obtained an explanation, that government policies in dealing with Covid-19 are sometimes not pro-people. Then those who were expose to Covid-19, received negative stereo types from others, then there were hospitals that took advantage of Covid-19 victims for an incentive. Paramedic services are not optimal for some patients, and there are still people who do not fully comply with health protocols. In a climate of social conditions that have begun to diminish the sense of humanity, it is fitting for believers (Christians) to become light and salt by practicing the universal truth of God's word through their deeds to others.
\end{abstract}

Key Words: Covid-19, Humanity, Caring, Believers

\section{Abstrak:}

Tulisan ini menyoroti mulai memudarnya rasa kemanusiaan terhadap sesama karena pengaruh Covid-19.Pengertian rasa kemanusiaan yang dimaksud dalam tulisan ini tentunya berangkat dari perspektif teologis Kristen. Adapun makna kemanusiaan yang dimaksud adanya empati atau kepedulian dalam memahami kesulitan yang dialami oleh orang lain, serta menjadi pelaku aktif dalam menanggulangi beban hidup orang lain tanpa mencari keuntungan. Metode yang dipakai dalam tulisan ini menggunakan kualitatif deskriptif dengan pendekatan fenomologis. Hasil dari pembahasan ini didapatkan suatu pemaparan, kebijakan pemerintah dalam penanggulangan Covid-19 terkadang tidak bersifat pro ke-rakyat. Kemudian mereka yang terpapar Covid-19, menerima streo type negatif dari sesama, kemudian adanya rumah sakit yang mengambil keuntungan dari korban Covid-19 demi sebuah insentif. Pelayanan tenaga medis yang tidak maksimal ke-sebagian pasien, serta masih dijumpainya masyarakat yang tidak sepenuhnya patuh pada protokol kesehatan. Iklim kondisi sosial yang mulai memudarkan rasa kemanusiaan, sudah sepatutunya orang percaya (Kristen) menjadi terang dan garam dengan mengamalkan kebenaran firman Allah secara menguniversal melalui perbuatannya kepada sesama.

Kata-kata Kunci: Covid-19, Kemanusiaan, kepedulian, orang Percaya. 


\section{Pendahuluan}

Tahun 2020 adalah tahun yang akan diingat oleh hampir seluruh umat manusia bahwa mereka menjalani fase kehidupan yang sukar sekaligus menyebabkan manusia menjadi mahluk yang mulai memudar sisi kemanusiaan atau kepeduliannya terhadap sesama. Penyebab dari itu adalah dunia dilanda pandemik atau wabah oleh Organisasi Kesehatan Dunia (WHO) menyebut sebagai Coronavirus Disease (Covid-19) yang diyakini penularannya berasal dari hewan kalilawar di Provinsi Hubei Tiongkok.(Adityo Susilo, 2020, hlm. 45) Pasca mewabahnya Covid-19 diberbagai negara, maka manusia menjalani rutinitas kehidupannya secara 180 derajat berbeda sebelum wabah Covid-19 menyeruak ke-permukaan.

Sisi perbedaan manusia dalam menjalankan rutinitas kehidupannya setelah Covid-19 menjalar adalah sekolah dan perkuliahan dilakukan secara virtual atau online. Efek dari pembelajaran secara daring ini, para pelajar dan mahasiswa merasa kesulitan dalam penyerapan ilmu. Demikian juga dengan para tenaga pendidik, mereka juga merasa kesulitan bagimana menemukan metode yang tepat dalam mengajar disituasi Covid-19 ini. Himbauan pemerintah agar pembelajaran dilakukan secara daring melalui Kementerian Pendidikan dan Kebudayaan yang melarang perguruan tinggi dan sekolah untuk melaksanakan perkuliahan dan pembelajaran tatap muka (konvensional) melalui Surat Edaran Kemendikbud Dikti No. 1 tahun 2020. Pembelajaran daring merupakan pembelajaran yang menggunakan jaringan internet dengan aksesibilitas, konektivitas, fleksibilitas, dan kemampuan untuk memunculkan berbagai jenis interaksi pembelajaran.(Ali Sadikin \& Afreni Hamidah, 2020, hlm. 215-216)

Begitu juga dalam menjalankan ritual peribadatan berdampak kepada masyarakat. Karena Covid-19 diyakini sebagai virus yang mudah menularkan kepada orang lain, maka perkumpulan massa yang banyak semestinya dilakukan di rumah sesuai intruksi pemerintah.("Jokowi tak Mau Ada Salah Paham Soal Imbauan Ibadah di Rumah | Republika Online," t.t.) Dengan merebaknya Covid-19, sisi perbedaan manusia dalam menjalankan rutinitas kehidupannya mulai berbeda dengan menjaga jarak terhadap sesama atau social distancing, menggunakan masker setiap saat, dan sebisa mungkin melakukan pekerjaannya dari rumah. Tujuannya agar tidak makin menambah jumlah yang terpapar Covid-19, maka sebisa mungkin masyarakat dihimbau membantu upaya pemerintah dalam menangani wabah ini. Hal yang paling sederhana dan paling efektif menekan dan memutus mata rantai penyebaran Covid -19 adalah untuk tidak keluar dan tetap di rumah saja, menjaga jarak, jika berada di tempat umum atau keramaian, menggunakan masker serta sering 
untuk mencuci tangan dan cukup istirahat agar kekebalan tubuh tetap terjaga dengan baik.(Syafrida \& Ralang Hartati, 2020, hlm. 505)

Dampak covid-19 juga menerjang perekonomian negara-negara di dunia, hal ini dikarenakan pertumbuhan perekonomian setiap negara mengalami stagnasi karena setiap negara terfokus pada penanganan pandemik ini. Ini pula yang dialami oleh perekonomian Indonesia, dampak dari wabah ini amat dirasakan oleh pekerja sektor informal, seperti ojek online, sopir angkot, pedang kaki lima, home industri, pekerja harian, nelayan, katering dan sektor UMKM dan non UMKM, seperti pusat perbelanjaan mal, supermarket, pusat jajanan makanan dan minuman, pemilik rumah aneka makanan modern, waralaba, omzetnya menurun dengan drastis karena pembeli sepi. Pelaku usaha banyak menutup usahanya karena daya beli masyarakat menurun.(Syafrida \& Ralang Hartati, 2020, hlm. 502) Selain itu faktor dibidang perdagangan dan pariwasata Indonesia, benar-benar babak belur karena Covid-19 ini. Jika ditahun 2019 ekspor Indonesia ke Cina mencapai USD25,85 miliar, sedangkan impor mencapai USD44,58 miliar. Namun berdasarkan data yang dikeluarkan BPS, ekspor non-migas pada Januari 2020 mengalami penurunan jika dibandingkan Desember 2019. Penurunan ini terjadi ke sebagian besar negara tujuan utama, salah satunya yaitu China yang mencapai USD211,9 juta atau turun 9,15\%. Sedangkan nilai impor nonmigas pada Januari 2020 juga ikut menurun.(Eka Budiyanti, 2020, hlm. 20)

Wabah Covid-19 yang menggonjang seluruh kehidupan umat manusia di muka bumi ini menyebabkan rasa kemanusiaan terhadap sesama mulai pudar karena manusia menjadi mahluk yang individualis atau mementingkan diri sendri sehingga perlahan-lahan sisi kepeduliannya terhadap sesama memudar. Pendapat senada dikemukakan oleh Daniel Covid-19 memberikan dampak pudarnya kemanusiaan secara pelan- pelan. Hal ini terlihat dari konflik-konflik kecil yang muncul, yang apabila dibiarkan akan menciderai sikap empati manusia. Berbagai kasus muncul ketika individu datang dari daerah yang disebut red zone atau luar negeri, yang menghasilkan ketakutan pada penduduk asal. Hal ini apabila dibiarkan akan menimbulkan sikap saling curiga ketika individu saling menduga-duga keterpaparan Covid-19.(Daniel Fajar Panuntun \& Eunike Paramita, 2020, hlm. 69) Memudarnya rasa kemanusiaan terhadap satu sama lain efek dari Covid-19 yang membawa setiap orang pada zona kesusahan hidup. Selain kesusahan hidup, wabah Covid-19 juga menyebabkan manusia menjadi paranoid terhadap satu sama lain. Sikap paranoid terhadap satu sama lain ini karena berbagai pemberitaan televisi yang menarasikan Covd-19 begitu ngeri dan seram karena tayangan media. Berita yang disiarkan televisi kepada penonton terkait Covid-19 pun muatan narasi-narasi ketakutan yang lebih dominan digemakan dibandingkan dengan narasi-narasi optimisme di masa 
pandemik ini. Penilain ini didasarkan pada ungkapan para netizen terkait isi narasi berita yang disiarkan.(SIMON, 2020, hlm. 121)

Berbagai contoh telah tersaji akibat dari dampak Covid-19 yang membuat mulai pudarnya sisi kemanusiaan terhadap sesama. Adapun contohnya seorang ibu di Banten Serang meninggal karena kelaparan akibat tidak punya penghasilan karena dampak dari Covid-19. Para netizen pun ikut menyayangkan tetangga dan pemerintah desa tidak terlihat perannya untuk membantunya.(“Yuli Telah Tiada, Begini Kondisi Terkini Keluarga yang Tak Makan 2 Hari Terimbas Virus Corona, YouTube," t.t.) Contoh lain masyarakat menolak pemakanan korban Covid-19, sebagian masyarakat menjauhi mereka yang dicap positif Covid-19. Dari peristiwaperistiwa yang terjadi itu dapat kita amati, bahwa akibat dari Covid-19 ini, secara perlahan memudarkan sisi kemanuisaan atau empati manusia terhadap satu sama lain. Rahardjo mengemukakan kemanusiaan adalah salah satu nilai dasar yang dijadikan pedoman dalam kehidupan berbangsa, bernegara dan bermasyarakat. Prinsip kemanusiaan yangmengandung ciri-ciri: pertama, mengandung nilai keadilan yakni kemanusiayang berkeadilan dan kedua, mengandung nilai keberadaban, yakni kemanusiaanyang berkeadaban. Makna kemanusiaan kerap kali lebih jelas jika berhadapandengan kasus-kasus yang bertentangan dengan perikemanusiaan.(Dawan M. Rahardjo, 1999, hlm. 49-50)

Tulisan ini secara spesifik membahas atau menguraikan mengenai memudarnya sisi kemanusiaan terhadap sesama pasca wabah covid-19 ini. Pengertian sisi kemanusiaan yang dimaksud dalam tulisan ini tentunya berangkat dari persfektif teologis Kristen. Adapun makna kemanusiaan adalah adanya empati atau kepedulian dalam memahami kesulitan yang dialami oleh orang lain, serta menjadi pelaku aktif dalam menanggulangi beban hidup orang lain tanpa mencari keuntungan. Ini sejalan dengan apa yang dikemukakanoleh Suardana bahwa identitas orang Kristen dalam realitas berbelas-kasihan adalah menampilkan kekayaan iman Kristen bukan dengan menjual keyakinan tetapi dengan membagi keyakinan berdasarkan kekayaan hati yang penuh kemurahan dan tergerak oleh belas kasihan. Orang tidak melihat apa yang kita pikirkan, tetapi apa yang kita bawa untuk kita lakukan dan memberi kehidupan kepada sesama.(I Made Suardana, 2015, hlm. 132) Garis besar yang akan diuraikan pada tulisan ini adalah perihal rasa kemanusiaan disituasi covid-19, dan bagaimana implikasinya terhadap orang percaya. Dengan membahas isu ini, tentunya bertujuan sebagai refleksi untuk kita lebih sadar agar mempertebal sisi kepedulian walau di masa kini semua orang mengalami kesulitan karena dampak Covid-19. Ke-bermanfaat tulisan ini untuk 
mendorong dan mengetuk sanubari pembaca, agar tidak memudar sisi kemanusiaan serta mengingatkan agar jangan sampai melupakan orang lain sesama ciptaan Allah.

\section{Metode Penelitian}

Abdurahman mengemukakan bahwa penelitian itu sebagai upaya atau kegiatan yang bertujuan untuk mencari jawaban yang sebenar-benarnya terhadap suatu kenyataan atau realita yang dipikirkan atau dipermasalahkan untuk memperoleh pengetahuan ilmiah tertentu yang berguna, baik bagi aspek keilmuan maupun bagi aspek kepraktisannya.(Maman Abdurahman, Sambas Ali Muhidin, 2011, hlm. 13) Sementara Sugiyo mengemukakan penelitian itu cara ilmiah untuk mendapatkan data dengan tujuan dan kegunaan tertentu. Berdasarkan pengertian tersebut terdapat empat yang perlu perlu dipahami lebih lanjut yaitu: cara ilmiah, data, tujuan dan kegunaan. Penelitian merupakan cara ilmiah, berarti penelitian itu didasarkan pada ciri keilmuannya seperti rasional,empiris dan sistematis.(Sugiyono, 2014, hlm. 1)Tulisan ini menggunakan metode deskriptif kualitatif dengan pendekatan studi fenomologis.Zaluchu mengemukakan pendekatan fenomologis memilih gejala atau fenomena sebagai titik tumpu penelitian, sehingga pengalaman manusia menjadi acuan pengamatan.Agama membawa penganutnya ke dalam pengalaman-pengalaman spiritual.Fenomena dari pengalaman-pengala-man itulah yang menjadi fokus penelitian.(Sonny Eli Zaluchu, 2020, hlm. 36)Rasa kemanusiaan pada situasi Covid-19 dideskripsikan dengan mengamati dan melihat baik dari lingkungan, media.Buku, jurnal serta berita dari website juga dipergunakan untuk menambah khasanan data faktual dalam penelitian ini.

\section{Rasa Kemanusiaan Disituasi Covid-19}

Kebijakan Pemerintah yang Terkadang Menyusahkan Masyarakat

Semenjak presiden Jokowi mengumumkan 2 Maret kasus perdana penularan covid-19 di Indonesia(“[TERBARU] Jokowi Umumkan 2 WNI Terinfeksi Virus Corona - YouTube," t.t.), sejak masa itu pula pemerintah mulai menyiapkan antisipasi dalam penanganan Covid-19. Wujud dari pengantisipasian yang dilakukan oleh pemerintah beragam, mulai dari penyiapan anggaran bagi korban Covid-19 yang didelegasikan kepada Lembaga Menteri Kesehatan(“Selain Pemotongan, Jokowi Tambah Anggaran Kemenkes-Kemendikbud dan Belanja Pemerintah Pusat Halaman all - Kompas.com," t.t.), pemberian bantuan kepada masyarakat dalam bentuk sembako, bantuan langsung tunai. Pemberian bantuan langsung tunai kepada usaha mikro kecil, bantuan berupa listrik gratis, potongan harga bagi yang tidak tersubsidi.(“Ada 7 Bantuan Pemerintah Selama Pandemi Covid-19, Berikut 
Rinciannya... Halaman all - Kompas.com," t.t.) Di samping kebijakan pemerintah yang memberikan bantuan, namun ada juga kebijakan pemerintah yang seakan membuat menipisnya kepedulian pemerintah dalam memandang kesusahan masyarakat.

Bentuk dari kebijakan pemerintah yang seakan tidak memperhatikan keluh kesah masyarakat adalah biaya rapid test dan sweb test yang mahal karena tidak masuk inkluf yang tercover oleh Badan Penjamin Jasa Kesehatan (BPJS), adanya PERPRES (peraturan presiden ) dan PERDA (peraturan daerah)pada pasal-pasal tertentu tentang pidana. Dengan adanya PERPRES dan PERDA yang mengatur masalah-masalah penanganan covid-19, ada pasal-pasal tertentu menurut masyarakat yang diambil pemerintah tidak iba dan peduli pada keluh kesah masyarakat. Di antara kebijakan-kebijakan pemerintah yang dikeluarkan dalam bentuk perpres dan perda berkaitan penangulangan Covid-19 adalah, pemberian denda hukuman dalam bentuk material, hukuman sosial denda, dan penjara bagi masyarakat yang tidak taat aturan protokol kesehatan. Kebijakan pemerintah yang mencetuskan aturan ini dianggap masyarakat justru lebih banyak yang kontra dibanding mereka yang pro. Tentunya penilaian ini berangkat dari bila melihat berbagai ragam komentar masyarakat (netizen) diberbagai media sosial. Pemberlakuan kebijakan mengenai aturan tersebut menuai reaksi yang beragam dimasyarakat. Mayoritas warga mengeluhkan dampak yang dialami seperti sulitnya ekonomi karena tidak dapat bekerja seperti biasa sehingga segala kebutuhan hidup tidak dapat terpenuhi dengan baik khususnya masyarakat kelas bawah.(Rindam Nasruddin \& Islamul Haq, 2020, hlm. 643)

Pihak yang kontra mengemukakan, dari pada membuat aturan yang menyusahkan masyarakat dan pengenaan denda disituasi di mana masyarakat sedang berada hidup susah karena Covid-19, mengapa pemerintah tidak mengeluarkan kebijakan dengan berpihak kepada rakyat. Wujud dari keberpihakan pemerintah tentang kebijakannya adalah memberikan hadih bagi masyarakat yang taat dalam menerapkan protokol kesehatan. Dengan adanya aturan pemerintah dalam bentuk perpres dan perda mengenai Covid-19 tentang denda dan pidana bagi pelanggar protokol kesehatan, aturan ini jugalah yang menyebabkan terkikisnya sisi kemanusiaan antara rakyat dengan rakyat dan pemimpinnya. Kartono mengemukakan perdebatan penerapan sanksi pidana terhadap pelanggar PSBB pun masih menjadi polemik dikalangan para akademisi, praktisi dan masyarakat. Apakah perlu para pelanggar PSBB ini dijerat sanksi pidana agar aturan ini berlaku secara maksimal. Dalam kaitannya dengan tujuan pemidanaan, terutama pencapaian efek jera bagi pelaku/pelanggar dan juga pencegahan secara umum dampak penyebaran 90 - Volume 1, Nomor 2, November 2020 
Covid-19.(Kartono, 2020, hlm. 688) Di satu sisi pemerntah ingin secepat mungkin wabah ini berlalu, namun kebijakan yang diambil terkadang membuat masyarakat menjadi susah dan menyuburkan sikap antipati rasa kemanusiaan kepada yang menderita.

\section{Korban Covid-19 Menerima Streo Type Negatif}

Sejak pemerintah mengumumkan Covid-19 telah masuk ke Indonesia, saat itu juga seakan masyarakat mengalami kepanikan massal. Masyarakat mengalami kepanikan karena media televisi dan media sosial seakan satu topik membahas Covid-19 dan memperlihatkan bagaimana ganasnya Covid-19 bagi korban yang terinfeksi. Berita dan pembahasan virus corona yang terus menerus di media massa cetak, elektronik dan media online serta sosial secara tidak langsung mempengaruhi warga, hingga membuat kepanikan dan kekhawatiran masyarakat. Berita yang keluar masuk melalui laman media sosial bisa bercampur antara berita valid dan berita hoax, sehingga berita mengenai Virus Corona semakin mendominasi bahkan bisa dikatakan berita mengenai Covid-19 memonopoli pemberitaan di Indonesia sepanjang tahun 2020 dan berita yang lain seolah tenggelam. Dalam hal ini, memaklumkan sebuah teori bahwa jika berita yang sama dimasukkan terus menerus dalam pemikiran/sajian maka akan menjadikan konstruksi media berupa tulisan atau liputan mampu yang menciptakan/mengkonstruksi realitas di mayarakat relevan dengan isi media. Artinya, jika media meliput betapa gawatnya virus Corona maka yang akan terkonstruksi pada pemikiran masyarakat adalah betapa gawatnya keadaan sekarang sehingga pada kondisi yang gawat ini apa yang harus disiapkan.(Heny Triyaningsih, 2020, hlm. 2-3)

Respon masyarakat yang mengarah pada kepanikan karena Covid-19 ini menyebabkan memudarnya sisi kemanusiaan di antara satu sama lain. Wujud dari memudarnya kemanusiaan terhadap satu sama lain, masyarakat menjadi sangat minim sikap empatinya dan tidak peka akan kesulitan di sekitarnya. Tidak hanya itu saja, tindakan paling ekstrim kepudaran kemanusiaan disituasi pandemik ini yang bisa kita lihat adalah, ramai-ramainya sebagian masyarakat di tanah air menolak pemakaman korban Covid-19 di tanah wakaf yang dekat dengan lingkungan mereka. Menjauhi orang yang terinfeksi karena Covid-19 juga merupakan hal-hal yang sering kita dengar dari televisi. Adanya penolakan pemakaman korban Covid-19, dijauhi oleh orang sekitar karena terpapar, sudah menunjukkan bahwa mereka yang terkena imbas dari wabah ini menerima perlakukan streo type negatif dari lingkungan dan orang terdekat. Tentunya korban dari yang mengalami streo type negatif ini akan mengalami pergejolakan batin karena kuatnya tekanan sosial yang dialami. Efek dari 
menerima tekanan sosial dari lingkungan, hingga menyebabkan ada yang bunuh diri karena tidak kuat menerima streo type negatif karena Covid-19 ini.(“Diduga Stres, 3 Pasien Positif Covid-19 Ini Nekat Lakukan Bunuh Diri," t.t.) Wardani menyatakan banyak warga yang mengalami kesedihan mendalam karena kematian anggota keluarga akibat wabah Covid-19. Kedukaan ini semakin bertambah dikarenakan adanya paranoid massal karena penularan penyakit akibat virus ini, sehingga banyak masyarakat menolak untuk mengurus dan memakamkan para korban yang meninggal akibat Covid-19.(Lavandya Permata Kusuma Wardani \& Daniel Fajar Panuntun, 2020, hlm. 45)

Peristiwa-peristiwa di atas menunjukkan betapa pudarnya sisi kemanusiaan atau rasa iba terhadap satu sama lain di masa pandemik ini. Sebagian orang sudah mulai melupakan bahwa kodratnya sebagai manusia adalah peka terhadap keadaan kemanusiaan di sekitarnya. Padahal natur manusiawi itu memanusiawi-kan orang lain untuk berbagi empati kepada sesama sebagai ciptaan Tuhan yang diciptakan dari sumber yang sama.

\section{Rumah Sakit yang Meng-covidkan Pasien}

Salah satu alokasi dana anggaran pendapatan belanja negara (APBN) yang digelontorkan oleh pemerintah adalah kepada penanggulangan wabah Covid-19. Melalui lembaga menteri kesehatan, negara mengkucurkan dana khusus penanganan Covid-19 kurang lebih 800 triliun rupiah. Dengan anggaran sebesar itu, maka untuk setiap per-pasian yang terpapar atau meninggal biaya rumah sakitnya kurang lebih lima puluh sampai Sembilan puluh juta rupiah.("Kemenkes: Biaya Perawatan Pasien Covid-19 Rata-rata Rp50 Juta," t.t.) Biaya ini sudah mencakup administrasi pelayanan, akomodasi ruang rawat inap, jasa dokter, pelayanan rawat jalan dan rawat inap, pemeriksaan penunjang diagnostik (laboratorium), obat, alat kesehatan, bahan medis habis pakai, alat pelindung diri (APD), ambulans rujukan hingga pemulasaran jenazah apabila pasien meninggal dunia.(“Pemerintah Menanggung Seluruh Biaya Pasien COVID-19," t.t.)

Dengan adanya jaminan insentif yang diberikan pemerintah kepada rumahrumah sakit yang menjadi rujukan pemerintah untuk penanggulangan Covid-19, maka di sebagian daerah didapati adanya rumah sakit yang nakal karena sengaja meng-covid-kan pasian demi insentif padahal pasien tersebut tidak terpapar covid19. Hal ini dikemukakan oleh ketua Badan Anggaran (Banggar) DPR RI Said Abdullah yang mengadu kepada Terawan tentang adanya rumah sakit "nakal" di sejumlah daerah. Menurutnya, rumah sakit tersebut sengaja membuat pasien dinyatakan positif Covid-19 demi mendapatkan anggaran corona. Ada kenakalan di 92 - Volume 1, Nomor 2, November 2020 
rumah sakit, tidak Covid tapi dinyatakan Covid.(“DPR ke Menkes Terawan: Ada RS Sengaja Bikin Pasien Positif Corona Demi Insentif - kumparan.com," t.t.) Pendapat senada diakui oleh Moeldoko selaku staf ke-presidenan mengemukakan sudah banyak informasi yang menyebutkan orang sakit biasa atau mengalami kecelakaan, didefinisikan meninggal karena terpapar Covid-19. Padahal sebenarnya, hasil tesnya juga negatif. Maka dari itu seperti ini perlu diluruskan, agar jangan sampai menguntungkan pihak- pihak yang ingin mencari keuntungan pasien yang dilabeli Covid-19.(“Isu Rumah Sakit 'Mengcovidkan' Pasien | Republika Online,” t.t.)

Merebaknya info sebagian rumah sakit secara sengaja meng-covid-kan pasien tentu bukanlah isapan jempol belaka saja. Ini ditandai adanya fakta-fakta di lapangan diberbagai daerah yang sebagian rumah sakit meng-covid-kan pasien. Contoh kasusnya, viralnya pasien di Banyuwangi yang di labeli Covid-19, ada juga kejadian di Medan, Purwakarta, dan sebagainya. Melihat fenomena adanya rumah sakit yang melabeli pasien Covid-19, demi sebuah insentif, sungguh memperlihatkan betapa pudarnya sisi kemanusiaan sebagian orang di masa pandemik ini. Tega mengambil keuntungan di atas penderitaan orang lain yang sedang kemalangan karena wabah, bukankah itu menunjukkan bentuk kejahatan yang tidak ada lagi rasa iba dan empati dalam merasakan kepedihan sesama manusia. Mengeruk rupiah dengan melabeli korban meninggal karena Covid-19 demi sebuah insentif, sungguh perbuatan yang tak berkeperi-manusaan. Dengan adanya Peristiwa-peristiwa semacam ini, mengindikasikan bahwa rasa kemanusiaan perlahan meluntur karena pengaruh Covid-19.

\section{Sebagian Tenaga Medis Tidak Maksimal Melayani Pasien Covid-19}

Berdasarkan data yang dirilis oleh Amnesty International, negara Indonesia berada di urutan kesepuluh dalam hal kematian tenaga medis dalam penanganan Covid-19. Data per-tiga September 2020, ada 181 tenaga medis yang meninggal. Usman Hamid menyebutkan dari 181 yang gugur itu 112 dokter dan 69 perawat.(“Amnesty: 181 Tenaga Medis Indonesia Gugur Akibat Covid-19 - Kabar24 Bisnis.com," t.t.) Di tengah keprihatinan banyaknya tenaga medis yang gugur karna merawatpasien yang terpapar Covid-19, maka pemerintah pun memberikan apresiasi kepada tenaga medis. Wujud dari apresiasi itu melalui pemberian dana insentif bagi para tenaga medis. Insentif diberikan berdasarkan perhitungan Kementerian Keuangan dan diberikan perbulan. Insentif terbagi atas sejumlah klaster. Untuk para dokter spesialis akan mendapatkan Rp 15 juta perbulan, dokter umum dan dokter gigi akan mendapatkan Rp 10 juta perbulan, sementara bidan dan perawat akan diberikan Rp7,5 juta perbulan dan tenaga medis lain akan mendapatkan Rp5 Juta 
perbulan. Apabila tenaga medis meninggal saat menangani pasien positif corona dan terpapar covid-19 akan mendapatkan santunan Rp300 juta.(Harisah, 2020, hlm. 523524)

Dengan diberikannya insentif bagi para tenaga medis dalam melayani masyarakat diharapkan semaksimal mungkin untuk merawat pasien-pasien yang terpapar Covid-19. Tetapi tidak bisa dipungkiri, berdasarkan aduan masyarakat dijumpai adanya oknum-oknum tenaga medis yang tidak maksimal merawat pasian Covid-19 bahkan ada bentuk kelalaian dilakukan hingga berujung pada musibah bagi sang pasien Covid-19. Adanya oknum-oknum yang lalai dan tidak maksimal merawat pasien Covid-19, karena mereka dihinggapi sikap paranoid atau ketakutan berlebihan tentang Covid-19 ini. Dampaknya menyebabkan berkurangnya perhatian oknum tenaga medis dalam memantau perkembangan kesehatan pasien karena ia kuatir akan terpapar. Akibat penangangan sebagian tenaga medis yang tidak maksimal, berita ibu hamil yang di Jombang ketika hendak mau melahirkan, justru tidak maksimal dilayani oleh tenaga medis, sehingga bayinya pun meninggal.("Pasien di Jombang Mengeluh Ditelantarkan Tenaga Medis," t.t.)Ada juga kasus Ayu Arianti warga Pejanggik, Kota Mataram, harus kehilangan bayinya yang meninggal dalam kandungan karena terlambat mendapatkan pertolongan dari tenaga medis.(“Kehilangan Bayi karena Harus Rapid Test Covid-19, Ayu Sudah Memohon ke Dokter: Tolong Saya Diperiksa - Tribun papua," t.t.)Ada juga kasus seorang ibu hamil di Padang Sidempuan yang mengeluhkan pelayanan tenaga medis yang tidak memadai, hingga akhirnya ia meninggal.("Beredar Video Live Facebook Ibu Hamil PDP Corona di Padang yang Meninggal, Keluhkan Layanan Isolasi YouTube," t.t.)

Kasus-kasus di atas menunjukkan, sikap paranoid oknum tenaga medis dalam merawat pasien menyebabkan masyarakat mengalami musibah karena pasien tidak dilayani secara maksimal dan sepenuh pengabdian.Dengan bersikap seperti itu, bukankah itu menunjukkan bahwa sisi kemanusiaan di masa pandemik ini terkikis karena sesama manusia mulai pudar sisi kepeduliannya dalam menolong mereka yang berada dalam penderitaan hidup. Sikap paranoid yang tumbuh di sebagian tenaga medis kerena pengaruh Covid-19, membuat hati nurani minim empati. Seharusnya seluruh tenaga medis harus kembali mengingat sumpah jabatan mereka untuk melayani masyarakat yang sakit secara tulus, iklas, ramah, dan professional walau nyawa taruhannya. Sikap Ke-paranoid-tan yang melanda pada sebagian tenada medis, menyebabkan pasien-pasien Covid-19 tidak terlayani secara baik, akibatnya terjadi hal-hal yang merugikan pasien itu sendiri. Padahal undang-undang 2009 nomor 36 pada pasal empat menyatakan bahwa "setiap orang berhak atas 94 - Volume 1, Nomor 2, November 2020 
kesehatan." Secara garis besar Undang- Undang tersebut mengisyaratkan bahwa setiap individu, keluarga dan masyarakat masuk ketentuan ke dalam UndangUndang Dasar 1945 dan Undang-Undang Kesehatan. Karena itu kesehatan tidak lagi hanya dikaitkan dengan nasib atau karunia Tuhan yang menjadi urusan pribadi setiap orang dan sama sekali tidak ada hubungannya dengan tanggung jawab negara, namun saat ini kesehatan telah menjadi suatu hak hukum (legal rights) yang dijamin, dilindungi, dihormati dan harus dipenuhi oleh negara.(Siti Nurhalimah, 2020, hlm. 546-547)

\section{Media Massa Menjadi Agen Penyebar Ketakutan}

Salah satu penyebab masyarakat tanah air menjadi paranoid hingga mengalami kepanikan massal akan Covid-19 karena pengaruh pemberitaan media massa. Padahal sejak Covid-19 melanda tanah air, menteri kesehatan seakan tersirat niatnya membangun kondisi keadaan tanah air agar tidak terjadi kepanikan massal atau masyarakat tergunjang jiwanya karena Covid-19. Namun karena peran media massa khususnya televisiyang terus memborbardir siaran Covid-19 tanpa henti ke tanah air, maka perubahan perilaku masyarakat berubah secara radikal jauh sebelum adanya Covid-19 melanda. Kuatnya pengaruh media dalam penyiaran Covid-19 mengakibatkan masyarakat menjadi mudah kuatir, paranoid. Hampir semua orang ketakutan dengan covid akibat propaganda yang dibesar-besarkan oleh media, tiap hari semua media mengutif jumlah korban terinfeksi dan kematian akibat covid, seharusnya media-media juga melakukan investigasi dan komparasi sendiri untuk memberi informasi yang lebih mencerahkan kepada publik. Berita yang lebih cenderung disiarkan televisi mengenai jumlah kematian karena Covid-19 kepada penonton, dikuatirkan dapat menyebabkan masyarakat menjadi makin resah dan kuatir.(SIMON, 2020, hlm. 120)

Tidak hanya ditelevisi bombastisnya pemberitaan mengenai Covid-19, media sosial seperti Facebook, Twieter, Instagram, Whatsap dan sejenisnya isi time line media sosial di dominasi oleh berita covid-19. Dengan dominasi berita Covid-19 di media sosial kita seakan digiring pada isi pembicaraan seputar virus corona. Efek dari itu, maka kita seakan tidak tahu lagi apakah berita-berita Covid-19 di time line media sosial itu bersifat fakta atau hoax. Di masa pandemik ini ada sebagian orang-orang yang hobi menyebarkan berita-berita Covid-19 tanpa disadari, pesan yang disebarkannya melalui Medsos dapat membuat sipenerima pesan menjadi takut maupun cemas. Karena itu tidak perlu menjadikan diri sebagai agen penyebar berita Covid-19 di Medsos, sebagaimana yang diperbuat oleh televisi.(SIMON, 2020, hlm. 128) 
Massifnya pemberitaan media massa mengenai covid-19 yang disertai dengan narasi-narasi ketakutan kepada penonton dalam penyiaran berita wabah ini, sebagian masyarakat menjadi mahluk yang tumpul hati nuraninya karena tidak lagi ikut berempati terhadap kesusahan orang lain. Pudarnya rasa kemanusiaan untuk berempati terhadap penderitaan orang lain disituasi pandemik ini, karena pengaruh media massa yang sudah membentuk pola pikir masyarakat melalui narasi yang seram tentang Covid-19. Dengan banyakya masyarakat menyerap informasi dari media massa mengenai Covid-19, maka berdampak pada respon dia dalam bersikap kepada sesama disituasi pandemik ini. Bentuk respon yang ditunjukkan akan mengarah pada sisi minusnya untuk mempedulikan sesamanya. Dalam konteks kehidupan sosial, masyarakat mempunyai persepsi awal terhadap sesuatu, namun persepsi tersebut dapat berubah disebabkan stimulus/pengaruh dari orang lain, lingkungan maupun dari media yang dikonsumsi. Media menjadi kekuatan yang mampu memberi dorongan untuk melakukan sesuatu.Dampak konsumsi media menjadikan konsumen media mengkonstruksi realitas sesuai dengan konstruksi media.(Heny Triyaningsih, 2020, hlm. 10)

\section{Masih Acuhnya Sebagian Masyarakat Terhadap Protokol Kesehatan}

Upaya yang dilakukan berbagai pemimpin dunia terhadap rakyat yang dipimpinnya dalam penanggulangan Covid-19 adalah dengan menyerukan social distancing, lockdown dan Pembatasan Sosial Berskala Besar (PSBB). Pemerintahan Indonesia sendiri mengambil kebijakan PSBB untuk mengatur ketertiban masyarakat dalam mencegah tidak makin bertambahnya jumlah yang terpapar Covid-19. PSBB adalah pembatasan kegiatan tertentu penduduk dalam suatu wilayah yang diduga terinfeksi Covid-19 sedemikian rupa untuk mencegah kemungkinan penyebaran Covid-19.(Imas Novita Juaningsih, Yosua Consuello, 2020) Selain itu pemerintah juga secara aktif mengkampanyekan kepada masyarakat untuk tetap menggunakan masker saat melakukan aktivitas di luar rumah. Penggunaan masker diyakini oleh pemerintah dapat mengurangi jumlah orang terpapar covid-19.

Melihat realita di lapangan, ditemukakan sebagian dari masyarakat masih acuhya serta tidak disiplinnya terhadap himbaun pemerintah dalam menaati protokolan kesehatan. Bentuk ketidak-patuhan itu tidak menggnakan masker, tidak sosiacl distancing, melakukan kerumunan massa dengan mengadakan hajatan nikahan, mengadakan konser musik dan sebagainya. Sikap yang ditunjukkan sebagian masyarakat dengan tidak patuh dan tidak disiplin, menunjukkan masih adanya sikap masa bodoh terhadap keadaan di masa pandemik ini. Buana mengemukakan banyak masyarakat yang tidak menyikapi hal ini dengan baik 96 - Volume 1, Nomor 2, November 2020 
tentang himbauan pemerinth mengenai protokol kesehatan, seperti contohnya adanya masyarakat yang memanfaatkan untuk berlibur, dilaksanakantabligh akbar, dimana akan berkumpul ribuan orang di satu tempat, yang jelas dapat menjadi penyebaran virus corona dalam skala yang jauh lebih besar. Selain itu masih banyak juga masyarakat Indonesia yang menganggap enteng virus ini, dengantidak mengindahkan himbauan-himbauan pemerintah.(Buana, 2020, hlm. 218-219)

Sikap sebagian masyarakat yang masih acuh dan masa bodoh, menyebabkan pemerintah dan tenaga medis kualahan mengatasi pandemik ini. Semakin banyak korban Covid-19, maka semakin banyak pula energi pemerintah melalui anggaran dana untuk menangani pasien Covid-19. Demikian juga para tenaga medis, mereka juga akan semakin kewalahan jika makin banyak masyarakat yang terpapar karena masih belum sepenuhnya menaati protokol kesehatan. Sikap acuh sebagain masyarakat terhadap situasi sekarang justru akan merugikan orang disekitar dan lingkungan. Jika sudah acuh tak acuh dengan himbauan pemerintah, itu perbuatan yang melanggar norma-norma kepedulian dan membuat orang lain bertambah susah. Dengan membuat orang lain susah, tentu itu mengikikis rasa kemanusiaan dengan tidak memperdulikan keadaan sekitar. Abai terhadap protokol kesehatan yang dapat merugikan orang lain adalah bagian dari pudarnya sisi kemanusiaan di masa pandemik ini.

\section{Implikasinya Bagi Orang Percaya}

Pandemi Covid-19 sudah melanda seluruh dunia dan semua orang secara global mau tidak mau, siap atau tidak, suka atau tidak, harus menjalani kehidupannya. Dengan situasi ini, maka tentunya kita sebagai orang percaya mengalami ketidak-pastian, kesepian, kekhawatiran, atau mungkun ketakutan, kepanikan (khususnya bila ada anggota keluarga yang terinfeksi), dan sangat mungkin, kehilangan harapan bagi masa depan (terutama bila sedang terbaring di ruang isolasi rumah sakit).(Daniel Lukas Lukito, 2020, hlm. 6) Di tengah kehidupan yang sulit, orang Kristen harus meyakini bahwa Allah dapat mendatangkan kebaikan bahkan di tengah keburukan pandemi ini sekalipun. Karena rancangan-Nya tidak bisa digagalkan oleh apapun, termasuk virus corona, meski sulit bagi kita untuk menerimanya dalam masa krisis ini. Pada saat yang sama, kitabertanggung jawab atas respon kita terhadap krisis ini dan terhadap sesamasebab Allah memberi kita kebebasan untuk merespons.(John C. Lennox, 2020, hlm. 46)

Walau semua orang diperhadapkan dengan permasalahan Covid-19, sebagai orang percaya (Kristen) sisi kemanusiaan atau empati terhadap sesama jangan memudar meskipun berbeda secara keyakinan dengan orang lain. Justru dengan kita 
menunjukkan ke-perhati-an dan rasa menolong terhadap orang lain, itu merupakan pengimplementasian iman kepada Kristus dalam wujud yang berbeda. Bila orang lain berubah sisi kemanusiannya dengan cenderung menjadi insan yang egois dan individualis karena efek Covid-19, orang percaya harus makin secara aktif menjadi role model bagaimana sebenarnya memanusiawikan orang lain. Sebab itu, gereja (orang percaya) diharapkan untuk terlibat serta dibutuhkan aksi nyata dan kontribusi terhadap permasalahan-permasalahan sosial di sekitarnya. Gereja dalam hal ini orang percaya tidak boleh diam bahkan menutup mata akan yang terjadi, karena Allah memanggil gereja-Nya untuk menjadi terang kepada orang lain.(Simon, 2019, hlm. 174)

Implikasi bagi orang percaya (Kristen) disituasi Covid-19 adalah semakin memperbesar rasa empati atau kepedulian terhadap sesama. Jika di masa kini kecenderungan rasa empati orang perlahan memudar karena pengaruh Covid-19, sudah sepatutnya orang percaya makin menebalkan sikap berbelas-kasihan dan kepekaan hati nurani melihat kesusahan orang lain. Yesus adalah contoh teladan yang baik dalam melihat sisi kemanusiannya terhadap orang lain. Ia ikut merasakan kesedihan Marta dan Maria ketika Lazarus meninggal (Yoh. 11:18), Yesus berempati kepada anak Yairus yang telah meninggal dengan dibangkitkan-Nya (Mar. 5:3542). Yesus menunjukkan belas-kasihan-Nya dengan menyembuhkan orang yang buta, menahirkan yang kusta, membuat yang bisu berbicara dan membangkitkan anak muda di Nain. Hal-hal yang diperbuat oleh Yesus ini adalah wujud dari rasa kemanusian-Nya dengan ikut merasakan apa yang dialami oleh orang disekitar-Nya. Berbelaskasihan adalah penegasan hidup Yesus kepada mereka yang membutuhkan pertolongan-Nya. Dalam pelayanan-Nya, Yesus memakai sebuah pendekatan melalui perumpamaan. Perumpamaan orang Samaria yang murah hati menegaskan pengajaran Yesus tentang sikap yang harus dibangun oleh orang Kristen terhadap sesama. Dengan membangun konsep berbelas-kasihan, Yesus menanggapi realitas kehidupan yang ditandai dengan berbagai pergumulan sosial dari orang- orang yang terpinggirkan, kaum miskin, kaum menderita, kaum perempuan dan anak-anak, bahkan kepada kaum atau bangsa yang dianggap kafir oleh orang Yahudi.(I Made Suardana, 2015, hlm. 125-126)

Dengan kita peka dan empati saat situasi pandemik ini, itu juga menunjukkan bagaimana orang percaya tidak menjadi egois serta tidak mencari keuntungan di atas kesusahan orang lain.Berbelas-kasihan kepada orang sekalipun itu berbeda secara kepercayaan, itu juga menunjukkan bagaimana kita menjadi manusia yang berbudi luhur, yang mengamalkan nilai-nilai rohani dalam firman Tuhan secara menguniversal bagi sesama insan manusia. Yosep mengemukakan relasi lintas iman 98 - Volume 1, Nomor 2, November 2020 
harus dibangun dengan sebuah kesadaran bahwa gereja maupun orang percaya dibentuk di dalam partikularitas dan kelokalan Gereja tidak pernah lepas dari lingkungan di mana dia hidup. Gereja adalah bagian dari masyarakat di mana gereja berada.Karena itu, masyarakatadalah "milik" gereja; sebaliknya, gereja adalah "milik" masyarakat.Segala keprihatinan masyarakat adalah juga keprihatinan gereja.(HARBELUBUN, 2017, hlm. 92)

Walau sebagian memudar rasa kemanusiannya dalam menunjukkan bentuk empati kepada orang lain pada situasi Covid-19, implikasinya bagi orang percaya (Kristen) adalah disiplin terhadap dirinya dan disiplin terhadap himbauan protokol kesehatan yang diserukan oleh pemerintah. Disiplin terhadap diri sendiri berupa menjaga dan merawat kebugaran tubuh jasmaninya dengan berpola hidup sehat.Sementara disiplin terhadap protokol kesehatan, dengan mengikuti himbauan pemerintah. Mengikuti himbauan pemerintah sudah menunjukkan partisipasi ikut membantu pemerintah dengan memperkecil jumlah korban Covid-19 yang terpapar.

Keikut-sertaan orang percaya dalam mentaati himbauan pemerintah mengenai protokol kesehatan juga menunjukkan bahwa orang percaya mengakui dan tunduk sepenuhnya kepada Allah yang diimplementasi-kan kepada pemerintah, sebab pemerintah merupakan wakil Allah di bumi untuk menata masyarakat agar hidup berbudi luhur dan bermoral dalam tatanan sosial. Pranoto mengemukakan negara dibutuhkan untuk mengatur kehidupan masyarakat agar tercipta keteraturan dan kestabilan. Mengatur masyarakat dengan jumlah skala yang besar tentu tidaklah mudah, perlu adanya suatu lembaga yang memiliki kuasa yang besar seperti negara untuk mengaturnya. Selain itu negara juga dibutuhkan agar manusia yang telah jatuh di dalam dosa tidak semakin menjadi kacau dan anarki oleh karena tidak ada yang mengontrolnya lagi. Karena itu setiap pemerintahan suatu negara menjadi mitra Allah yang menyandang kuasa untuk menegakkan keadilan bagi yang bersalah (Rm. 13:4; bnd. 1Ptr. 2:14).(Minggus Minarto Pranoto, 2009, hlm. 5)

Kemudian implikasi bagi orang percaya agar tidak sampai terpengaruh karena mulai berkurangnya sisi kepedulian terhadap sesama adalah tidak terlalu paranoid atau berlebihan atau ketakutan mengenai Covid-19 ini.Tidak bisa dipungkiri, mulai lunturnya sisi kemanusiaan orang-orang untuk berempati terhadap penderitaan orang lain, karena terlalu parnonya kepada Covid-19. Bersikap waspada harus, namun bersikap paranoid hingga menyebabkan rasa kemanusiannya pudar tidak peduli pada orang lain adalah tindakan yang memperlihatkan pudarnya rasa kemanusiaan disituasi Covid-19. Sekalipun orang percaya (Kristen) melihat orangorang disekitar larut dalam kepanikan massal karena Covid-19, tetap jadikan firman Allah sebagai penangkal untuk melawan histeria paranoid yang menjangkiti orang 
pada umumnya. Bukankah Alkitab menulis “ Engkau tak usah takut terhadap kedahsyatan malam, terhadap panah yang terbang di waktu siang, terhadap penyakit sampar yang berjalan di dalam gelap, terhadap penyakit menular yang mengamuk di waktu petang. (Maz. 91:56). Pradipta menyatakan berkaitan teks ini secara umum, orang Kristen akan berdoa dan memperkatakan janji Firman Tuhan yang berisi perlindungan serta keselamatan terhadap serangan penyakit seperti COVID-19, khususnya kitab Mazmur 91 maupun bagian teks Alkitab yang lain. Bahkan pendeta maupun gembala menekankan pentingnya pembacaan, penghafalan, di dalam menghalau wabah penyakit, dalam konteks sekarang khususnya COVID-19.(D. A. Pradipta, 2020, hlm. 133)

Orang percaya (Kristen) jangan sampai terbawa arus dengan bersikap paranoid secara berlebihan sebagaimana sikap paraoind ini menjadi fenomena di lingkup masyarakat. Akibatnya berujung pada menipiskan rasa kemanusiaan untuk ikut berempati terhadap permasalahan orang di sekitar. Dengan tidak terjebak pada fenoma kekuatiran massal karena Covid-19, itu menunjukkan diri dan keiman kita tidak dikendalikan dan tidak larut dalam suasana yang seram. Dengan tidak bersikap paranoid, kita dapat memberi dukungan moril, menghadirkan diri bagi mereka yang tersisihkan karena dilabeli Covid-19, serta menjadi penebar harapan bagi yang sudah kehilangan semangat hidup. Piper berkata pengharapan adalah kekuatan; kekuatan di masa Covid-19. Pengharapan mencegah orang-orang untuk bunuh diri dan berputus asa. Pengharapan menolong orang-orang tetap survive sekalipun mungkin di-isolasi, karantina, dan pengharapan membebaskan kita dari ketakutan yang egois dan ketamakan.(Piper, 2020, hlm. 13)

\section{Kesimpulan}

Covid-19 telah menyebabkan masyarakat Indonesia seakan dibawa pada fase dalam menjalani kehidupan yang rumit. Gambaran kehidupan yang rumit itu ditandai dengan tidak bisanya menjalani kehidupan yang normal sebelum wabah melanda. Bagi para pelajar dan mahassiwa, mereka merasa sulit belajar karena daring, melaksanakan kegiatan peribadatan pun menjadi kurang optimal karena dilakukan dirumah atau mengikuti secara on-line. Covid-19 juga membuat banyak masyarakat mengalami kesusahan secara finansial karena terganggunya aktivitas dalam bekerja dan berusaha. Gejolak kehidupan masyarakat karena Covid-19, membuat masyarakat menjadi mahluk yang individualis dan tak berempati dengan tidak lagi punya rasa iba melihat manusia yang menderita di sekitarnya. Terjadinya degradasi rasa kemanusiaan disituasi pandemik ini, menjadi peringatan bagi orang percaya agar jangan sampai rasa ke-manusiaannya dan empatinya terkikis hanya karena ia juga 100 - Volume 1, Nomor 2, November 2020 
dihadapkan pada situasi pandemik ini. Jika orang lain sisi kepeduliannya pudar dan menumpul belas-kasihannya, maka orang percaya harus semakin menunjukkan kepedulian, kemurahan hati untuk ikut sepenanggungan melihat kesulitan hidup manusia di sekitarnya.

\section{Daftar Pustaka}

Ada 7 Bantuan Pemerintah Selama Pandemi Covid-19, Berikut Rinciannya...

Halaman all-Kompas.com. (t.t.). Diambil 17 Oktober 2020, dari https:/ / nasional.kompas.com/read/2020/08/26/09222471/ada-7-bantuanpemerintah-selama-pandemi-covid-19-berikut-rinciannya?page=all 
Adityo Susilo. (2020). Coronavirus Disease 2019: Tinjauan Literatur Terkini" Jurnal Penyakit Dalam Indonesia. Jurnal Penyakit Dalam Indonesia, 7(1).

Ali Sadikin \& Afreni Hamidah. (2020). Pembelajaran Daring di Tengah Wabah Covid-19. BIODIK: Jurnal Ilmiah Pendidikan Biologi, 6(2).

Amnesty: 181 Tenaga Medis Indonesia Gugur Akibat Covid-19-Kabar24

Bisnis.com. (t.t.). Diambil 15 Oktober 2020, dari https://kabar24.bisnis.com/read/20200905/15/1287751/amnesty-181tenaga-medis-indonesia-gugur-akibat-covid-19

Beredar Video Live Facebook Ibu Hamil PDP Corona di Padang yang Meninggal, Keluhkan Layanan Isolasi-YouTube. (t.t.). Diambil 15 Oktober 2020, dari https:/ / www.youtube.com/watch?v=kCv3KcQ2ZH4

Buana, D. R. (2020). Analisis Perilaku Masyarakat Indonesia dalam Menghadapi Pandemi Virus Corona (Covid-19) dan Kiat Menjaga Kesejahteraan Jiwa. Sosial \& Budaya Syar-i, 7(3).

D. A. Pradipta. (2020). PENAFSIRAN TEKS MAZMUR 91 YANG BENAR DALAM MEREFLEKSIKAN PERISTIWA PANDEMI COVID 19. Jurnal Gamaliel : Teologi Praktika, 2(2).

Daniel Fajar Panuntun \& Eunike Paramita. (2020). HOSPITALITAS KRISTEN DAN TANTANGANNYA DI TENGAHPANDEMI COVID-19. Harmoni, 19(1).

Daniel Lukas Lukito. (2020). IMAN KRISTEN DI TENGAH PANDEMI. Malang: SAAT.

Dawan M. Rahardjo. (1999). Islam dan Transformasi Sosial Ekonomi. Jakarta: LSAF. Diduga Stres, 3 Pasien Positif Covid-19 Ini Nekat Lakukan Bunuh Diri. (t.t.). Diambil 14 Oktober 2020, dari https:/ /jogja.suara.com/read/2020/09/04/104354/diduga-stres-3-pasienpositif-covid-19-ini-nekat-lakukan-bunuh-diri?page=all

DPR ke Menkes Terawan: Ada RS Sengaja Bikin Pasien Positif Corona Demi Insentif-Kumparan.com. (t.t.). Diambil 14 Oktober 2020, dari https:/ / kumparan.com/kumparanbisnis/dpr-ke-menkes-terawan-ada-rssengaja-bikin-pasien-positif-corona-demi-insentif-1toB4JUCDAn/full

Eka Budiyanti. (2020). DAMPAK VIRUS CORONA TERHADAP SEKTOR PERDAGANGAN DAN PARIWISATA INDONESIA. KAJIAN SINGKAT TERHADAP ISU AKTUAL DAN STRATEGIS, 12(4).

HARBELUBUN, Y. (2017). MEMBANGUN PERSAUDARAAN LINTAS IMAN DENGAN BERBASIS PADA KEBUDAYAAN MASYARAKAT ADAT KEI. GEMA TEOLOGI, 2(1).

Harisah. (2020). Kebijakan Pemberian Insentif Pada Tenaga Medis Virus Corona Covid-19; Pendekatan Maslahah. SALAM; Jurnal Sosial \& Budaya Syar-i, 7(6).

Heny Triyaningsih. (2020). Meyarsa, Vol. 1 No. 1, Juni 2020 EFEK PEMBERITAAN MEDIA MASSA TERHADAP PERSEPSI MASYARAKAT PAMEKASAN TENTANG VIRUS CORONA. Meyarsa, 1(1).

I Made Suardana. (2015). IDENTITAS KRISTEN DALAM REALITAS HIDUP BERBELASKASIHAN: MEMAKNAI KISAH ORANG SAMARIA YANG MURAH HATI. Jaffray, 13(1). 
Imas Novita Juaningsih, Yosua Consuello, A. T. \& N. D. (2020). Optimalisasi Kebijakan Pemerintah Dalam Penanganan Covid-19 Terhadap Masyarakat Indonesia. SALAM; Jurnal Sosial \& Budaya Syar-i, 7(6).

Isu Rumah Sakit 'Mengcovidkan' Pasien | Republika Online. (t.t.). Diambil 14 Oktober 2020, dari https:/ / republika.co.id/berita/ qhijf9396/isu-rumah-sakitmengcovidkan-pasien

John C. Lennox. (2020). WHERE IS GOD IN A CORONAVIRUS WORLD? (1 ed.; V. Lengkong, Ed.). Surabaya: LITERATUR PERKANTAS JATIM.

Jokowi tak Mau Ada Salah Paham Soal Imbauan Ibadah di Rumah | Republika Online. (t.t.). Diambil 10 Oktober 2020, dari https:/ / republika.co.id/berita/qakagk354/jokowi-tak-mau-ada-salahpaham-soal-imbauan-ibadah-di-rumah

Kartono. (2020). Pembatasan Sosial Berskala Besar (PSBB) Dan Pidana Denda Dalam Rangka Pencegahan dan Pemberantasan Pandemi Coronavirus Disease (Covid)-19. SALAM; Jurnal Sosial \& Budaya Syar-i, 7(8).

Kehilangan Bayi karena Harus Rapid Test Covid-19, Ayu Sudah Memohon ke Dokter: Tolong Saya Diperiksa - Tribun papua. (t.t.). Diambil 15 Oktober 2020, dari https:/ / papua.tribunnews.com/2020/08/21/kehilangan-bayikarena-harus-rapid-test-covid-19-ayu-sudah-memohon-ke-dokter-tolongsaya-diperiksa

Kemenkes: Biaya Perawatan Pasien Covid-19 Rata-rata Rp50 Juta. (t.t.). Diambil 14 Oktober 2020, dari https:/ / www.cnbcindonesia.com/news/202006111907394-164770/kemenkes-biaya-perawatan-pasien-covid-19-rata-rata-rp50-juta

Lavandya Permata Kusuma Wardani \& Daniel Fajar Panuntun. (2020). PELAYANAN PASTORAL PENGHIBURAN KEDUKAAAN BAGI KELUARGA KORBAN MENINGGAL AKIBAT CORONAVIRUS DISEASE 2019 (COVID-19). KENOSIS, 6(1).

Maman Abdurahman, Sambas Ali Muhidin, A. S. (2011). Dasar-Dasar Metode Statistika untuk Penelitian. Bandung: CV Pustaka Setia.

Minggus Minarto Pranoto. (2009). RELASI GEREJA DENGAN NEGARA Sebuah Perspektif Teologi Kristen. Jurnal Amanat Agung, 5(1).

Pasien di Jombang Mengeluh Ditelantarkan Tenaga Medis. (t.t.). Diambil 15 Oktober 2020, dari http:/ / surabayapagi.com/read/pasien-di-jombang-mengeluhditelantarkan-tenaga-medis

Pemerintah Menanggung Seluruh Biaya Pasien COVID-19. (t.t.). Diambil 14 Oktober 2020, dari https:/ / www.kemenkeu.go.id/publikasi/berita/pemerintahmenanggung-seluruh-biaya-pasien-covid-19/

Piper, J. (2020). CORONA VIRUS AND CHRIST (1 ed.; Vionatha Lengkong, Ed.). Surabaya: LITERATUR PERKANTAS JATIM.

Rindam Nasruddin \& Islamul Haq. (2020). Pembatasan Sosial Berskala Besar (PSBB) dan Masyarakat Berpenghasilan Rendah $\square$. SALAM; Jurnal Sosial E Budaya Syar-i, 7(7).

Selain Pemotongan, Jokowi Tambah Anggaran Kemenkes-Kemendikbud dan Belanja Pemerintah Pusat Halaman all-Kompas.com. (t.t.). Diambil 14 Oktober 2020, dari https:// nasional.kompas.com/read/2020/04/13/08351891/ selain- 
pemotongan-jokowi-tambah-anggaran-kemenkes-kemendikbud-danbelanja?page $=$ all

SIMON. (2020). RESPON ORANG KRISTEN TERHADAP PEMBERITAAN TELEVISI MENGENAI COVID-19. Jurnal Gamaliel : Teologi Praktika, 2(2).

Simon, S. (2019). Peranan Gereja dalam Menghambat Laju Pertumbuhan Pemakai Narkoba. Jurnal Ilmiah Religiosity Entity Humanity (JIREH), 1(2), 172-186. https:// doi.org/10.37364/jireh.v1i2.15

Siti Nurhalimah. (2020). Covid-19 dan Hak Masyarakat atas Kesehatan. SALAM; Jurnal Sosial \& Budaya Syar-i, 7(6).

Sonny Eli Zaluchu. (2020). Strategi Penelitian Kualitatif Dan Kuantitatif Di Dalam Penelitian Agama. Evangelikal: Jurnal Teologi Injili dan Pembinaan Warga, 4(1).

Sugiyono. (2014). Statistika untuk Penelitian (Cetakan ke). Bandung: ALFABETA.

Syafrida \& Ralang Hartati. (2020). Bersama Melawan Virus Covid 19 di Indonesia. SALAM; Jurnal Sosial \& Budaya Syar-i, 7(6).

[TERBARU] Jokowi Umumkan 2 WNI Terinfeksi Virus Corona - YouTube. (t.t.). Diambil 14 Oktober 2020, dari https://www.youtube.com/watch?v=4Mw_oK3WCtw

Yuli Telah Tiada, Begini Kondisi Terkini Keluarga yang Tak Makan 2 Hari Terimbas Virus Corona, - YouTube. (t.t.). Diambil 12 Oktober 2020, dari https://www.youtube.com/watch?v=Nmdlmm5kg_4 